OPEN ACCESS

Edited by:

George Perry,

University of Texas at San Antonio,

United States

Reviewed by:

Samuele Cortese,

University of Southampton,

United Kingdom

*Correspondence:

Brandy L. Callahan brandy.callahan@ucalgary.ca

Received: 30 November 2021 Accepted: 28 December 2021 Published: 25 January 2022

Citation:

Becker S, Sharma MJ and Callahan BL (2022) ADHD and Neurodegenerative Disease Risk: A Critical Examination of the Evidence. Front. Aging Neurosci. 13:826213. doi: 10.3389/fnagi.2021.826213

\section{ADHD and Neurodegenerative Disease Risk: A Critical Examination of the Evidence}

\author{
Sara Becker ${ }^{1,2}$, Manu J. Sharma ${ }^{1,2}$ and Brandy L. Callahan ${ }^{1,2 *}$ \\ ${ }^{1}$ Department of Psychology, University of Calgary, Calgary, AB, Canada, ${ }^{2}$ Hotchkiss Brain Institute, University of Calgary, \\ Calgary, $A B$, Canada
}

In this review, we undertake a critical appraisal of eight published studies providing first evidence that a history of attention-deficit/hyperactivity disorder (ADHD) may increase risk for the later-life development of a neurodegenerative disease, in particular Lewy body diseases (LBD), by up to five-fold. Most of these studies have used data linked to health records in large population registers and include impressive sample sizes and adequate follow-up periods. We identify a number of methodological limitations as well, including potential diagnostic inaccuracies arising from the use of electronic health records, biases in the measurement of ADHD status and symptoms, and concerns surrounding the representativeness of $A D H D$ and $L B D$ cohorts. Consequently, previously reported risk associations may have been underestimated due to the high likelihood of potentially missed ADHD cases in groups used as "controls", or alternatively previous estimates may be inflated due to the inclusion of confounding comorbidities or non-ADHD cases within "exposed" groups that may have better accounted for dementia risk. Prospective longitudinal studies involving well-characterized cases and controls are recommended to provide some reassurance about the validity of neurodegenerative risk estimates in ADHD.

\section{Keywords: aging, Alzheimer disease, attention deficit disorder with hyperactivity, dementia, Parkinson disease,} synucleinopathies, attention-deficit/hyperactivity disorder

\section{INTRODUCTION}

Attention-deficit hyperactivity disorder (ADHD) is a psychiatric disorder beginning in childhood that is characterized by core symptoms of inattention, impulsivity, and hyperactivity (Biederman and Faraone, 2005; American Psychiatric Association, 2013; Faraone et al., 2015). Diagnostic criteria require symptoms to present in early childhood, before age 12, and cause impairment in daily activities in more than one setting (e.g., home, school, social environment, and/or interpersonal relationships; American Psychiatric Association, 2013). Although it is largely considered a childhood disorder, $40-60 \%$ of cases of ADHD persist into adulthood (Culpepper and Mattingly, 2010; Michielsen et al., 2012; Volkow and Swanson, 2013; Asherson et al., 2016), and the overall prevalence of adult 
ADHD ranges from 2 to 4\% (Kieling and Rohde, 2012; Fayyad et al., 2017).

ADHD may persist into later life as well. Roughly 3\% of adults over age 50 suffer from significant symptoms of attention-deficit/hyperactivity disorder (ADHD; Michielsen et al., 2012; Kooij et al., 2016), often presenting as executive dysfunction (e.g., absent-mindedness) and memory impairments (e.g., forgetfulness or difficulty learning new things; Rosler et al., 2010; Thorell et al., 2017; Callahan et al., 2021). These symptoms overlap with those of early neurodegenerative disease (Ivanchak et al., 2012; Pollack, 2012; Goodman et al., 2016; Callahan et al., 2017), and it is currently unclear whether ADHD is associated with an increased neurodegenerative risk, or if it is being misdiagnosed due to symptom overlap (Callahan et al., 2017). Clarifying this issue is crucial to reduce dementia misdiagnoses, and to guide treatment, which will differ depending on whether the disease course is assumed to be neurodegenerative or not.

Some data have suggested a link between ADHD and neurodegenerative disease, which appears to be specific to Lewy body diseases (LBD; Baumeister, 2021). Lewy body diseases refer inclusively to Parkinson's disease, Parkinson's disease dementia, and dementia with Lewy bodies, which are assumed to be different phenotypic expressions of underlying $\alpha$-synuclein pathology (Gomperts, 2016). All three share clinical and neuropathological findings, including motor symptomatology (i.e., parkinsonism), progressive executive dysfunction, and non-motor symptoms such as autonomic dysfunction, sleep behavior disorders, hallucinations, and olfactory dysfunction (Aarsland, 2016; Sezgin et al., 2019). Motor abnormalities (Goulardins et al., 2017), executive dysfunction (Barkley, 1997), and disordered sleep (Konofal et al., 2010) are also present in ADHD, which has generated research interest in the relationship between these syndromes.

In the last 15 years, eight published studies have suggested that ADHD may be a risk factor for incident neurodegeneration (Walitza et al., 2007; Golimstok et al., 2011; Curtin et al., 2018; Fluegge and Fluegge, 2018; Tzeng et al., 2019; Fan et al., 2020; Du Rietz et al., 2021; Zhang et al., 2021; see Table 1). These studies have primarily used data from population registers with linked health information (Curtin et al., 2018; Du Rietz et al., 2021; Zhang et al., 2021), healthcare utilization databases (Fluegge and Fluegge, 2018), or health insurance databases (Tzeng et al., 2019), and have reported increased risk for neurodegeneration-particularly LBD-in individuals with antecedent ADHD. Two smaller retrospective case-control studies have similarly reported increased earlier-life ADHD symptoms in individuals with Parkinson's disease relative to controls (Walitza et al., 2007; Golimstok et al., 2011). Hazard ratios in these studies range from 1.8 to 5.2 and odds ratios range from 1.5 to 5.1 (Table $\mathbf{1}$ ), suggesting strongly increased risk of later-life dementia in individuals with antecedent ADHD, even after controlling for potential confounds such as diabetes (Fluegge and Fluegge, 2018) or stimulant medication use (Curtin et al., 2018).

A recent review (Baumeister, 2021) summarized findings from five of these eight studies, and thoroughly described alterations in dopaminergic, cognitive, and neural functioning that are common to both ADHD and Parkinson's disease in an attempt to understand the etiology and pathogenesis of both disorders. Here, we extend this discussion to address three new studies published in 2020 and 2021, and take a more critical perspective in appraising this literature. We argue that the evidence presented in these eight studies deserves very careful consideration, because its corollary is that ADHD may represent a preclinical or risk stage of neurodegeneration during which important decision-making and early intervention may be possible.

\section{CRITICAL APPRAISAL OF METHODOLOGICAL APPROACHES}

\section{Electronic Health Records}

The use of health administrative data enables population-level analyses, improves generalizability of results, and minimizes referral bias (Benchimol et al., 2011). The systematic collection of data over time is particularly beneficial for studying both neurodevelopmental and neurodegenerative disorders. However, there are limitations in using such data, including misclassifications and coding or data entry errors, as well as changes in both diagnostic criteria and coding systems over time (Mazzali et al., 2016).

In four studies (Curtin et al., 2018; Fluegge and Fluegge, 2018; Tzeng et al., 2019; Du Rietz et al., 2021), ADHD participants were identified via health record diagnostic codes from the International Classification of Diseases (ICD), and the authors evaluated the risk of subsequent basal ganglia diseases including LBD (Curtin et al., 2018; Du Rietz et al., 2021) or Lewy body or Alzheimer's dementias (Fluegge and Fluegge, 2018; Tzeng et al., 2019; Du Rietz et al., 2021) associated with these codes. Another study (Zhang et al., 2021) investigated the relationship between familial aggregation of ADHD and dementia using both ICD-9 and ICD-10 codes. Not all studies, however, included consistent or intuitive operationalizations of ADHD (Table 1). For instance, two (Tzeng et al., 2019; Zhang et al., 2021) considered inattentive, hyperactive, and combined ADHD presentations (codes 314.00-01), while another (Fluegge and Fluegge, 2018) only considered hyperactivity presentations (314.01). Thus, ADHD cases presenting without hyperactivity - which represent between 20\% (Salvi et al., 2019) and 40\% (Gibbins et al., 2010) of adult cases-were not captured in the Fluegge and Fluegge (2018) study, suggesting the sample was an incomplete representation of ADHD. In contrast, two other studies (Curtin et al., 2018; Du Rietz et al., 2021) included hyperkinetic disorders within their ADHD designation (codes 314.0-314.2, 314.8, 314.9), which is problematic because the criteria for these categories are not well defined, and misdiagnoses are common [e.g., hyperkinetic movement disorders may be mistaken for tics or Tourette's syndrome (Kompliti and Goetz, 1998)]. Hyperkinetic disorders are also characterized by excessive involuntary movements resulting from basal ganglia damage (Wichmann and DeLong, 2010), so their consideration as a risk factor for basal ganglia diseases such as LBD is somewhat tautological.

There is also considerable variability in the disorders encompassed by the diagnostic codes used to define LBD 
TABLE 1 | Summary of eight studies investigating relationships between antecedent ADHD and later-life neurodegenerative diseases.

\begin{tabular}{|c|c|c|c|c|c|c|c|c|}
\hline & $\begin{array}{l}\text { Walitza et al. } \\
\text { (2007) }\end{array}$ & $\begin{array}{l}\text { Golimstok et al. } \\
\text { (2011) }\end{array}$ & $\begin{array}{l}\text { Curtin et al. } \\
\text { (2018) }\end{array}$ & $\begin{array}{l}\text { Fluegge and } \\
\text { Fluegge (2018) }\end{array}$ & $\begin{array}{l}\text { Tzeng et al. } \\
\text { (2019) }\end{array}$ & Fan et al. (2020) & $\begin{array}{l}\text { Du Rietz et al. } \\
\text { (2021) }\end{array}$ & $\begin{array}{l}\text { Zhang et al. } \\
\text { (2021) }\end{array}$ \\
\hline Objective & $\begin{array}{l}\text { To quantify ADHD } \\
\text { symptoms that } \\
\text { preceded PD } \\
\text { onset, accounting } \\
\text { for exposure to } \\
\text { psychostimulants. }\end{array}$ & $\begin{array}{l}\text { To determine } \\
\text { whether ADHD } \\
\text { symptoms } \\
\text { precede the } \\
\text { onset of clinical } \\
\text { DLB. }\end{array}$ & $\begin{array}{l}\text { To investigate } \\
\text { whether } \\
\text { antecedent } \\
\text { ADHD is linked to } \\
\text { increased } \\
\text { incidence of } \\
\text { BG\&C diseases. }\end{array}$ & $\begin{array}{l}\text { To determine the } \\
\text { role of } \\
\text { antecedent } \\
\text { ADHD in } \\
\text { dementia risk. }\end{array}$ & $\begin{array}{l}\text { To clarify the } \\
\text { association } \\
\text { between adults } \\
\text { with ADHD and } \\
\text { the risk of } \\
\text { dementia. }\end{array}$ & $\begin{array}{l}\text { To determine } \\
\text { whether PD } \\
\text { patients exhibit a } \\
\text { greater } \\
\text { propensity for } \\
\text { prior ADHD than } \\
\text { controls. }\end{array}$ & $\begin{array}{l}\text { To investigate } \\
\text { associations } \\
\text { between ADHD } \\
\text { and a wide range } \\
\text { of physical health } \\
\text { conditions across } \\
\text { adulthood. }\end{array}$ & $\begin{array}{l}\text { To evaluate } \\
\text { cross-generation } \\
\text { familial } \\
\text { aggregation of } \\
\text { ADHD and } \\
\text { Alzheimer's } \\
\text { Disease/any } \\
\text { dementia. }\end{array}$ \\
\hline Participants & $\begin{array}{l}88 \text { healthy controls } \\
88 \text { PD } \\
\text { (43 early-onset) }\end{array}$ & $\begin{array}{l}149 \text { healthy controls } \\
109 \mathrm{DLB} \\
251 \mathrm{AD}\end{array}$ & $\begin{array}{l}158,790 \text { controls } \\
31,769 \mathrm{ADHD}\end{array}$ & $\begin{array}{l}\text { No sample sizes } \\
\text { specified other } \\
\text { than "162 } \\
\text { state-year } \\
\text { observations" }\end{array}$ & $\begin{array}{l}2,025 \text { controls } \\
675 \mathrm{ADHD}\end{array}$ & $\begin{array}{l}10,726 \text { controls } \\
10,726 \text { PD }\end{array}$ & $\begin{array}{l}4,789,799 \text { cases; } \\
61,960 \text { (1.29\%) } \\
\text { had lifetime } \\
\text { prevalence of } \\
\text { ADHD }\end{array}$ & $\begin{array}{l}2,132,929 \text { index } \\
\text { persons and their } \\
\text { relatives (parents, } \\
\text { grandparents, } \\
\text { and aunt/uncles) }\end{array}$ \\
\hline $\begin{array}{l}\text { Definition of } \\
\text { ADHD }\end{array}$ & $\begin{array}{l}\text { WURS-k total } \\
\text { score as the } \\
\text { primary outcome } \\
\text { of interest (also } \\
\text { reported WURS-k } \\
\geq 30 \text { for clinical } \\
\text { childhood } \\
\text { diagnosis). }\end{array}$ & $\begin{array}{l}\text { WURS } \geq 32 \text { for } \\
\text { retrospective } \\
\text { diagnosis of } \\
\text { childhood ADHD; } \\
\text { DSM-IV criteria } \\
\text { for diagnosis of } \\
\text { adult ADHD. }\end{array}$ & $\begin{array}{l}\text { ICD-9 codes } \\
314.00 \text { and } \\
314.01 \text { (ADD } \\
\text { without and with } \\
\text { hyperactivity), } \\
314.1 \\
\text { (hyperkinesis with } \\
\text { developmental } \\
\text { delay), } 314.2 \\
\text { (hyperkinetic } \\
\text { conduct } \\
\text { disorder), } \\
314.8 \text { and } 314.9 \\
\text { (other or } \\
\text { unspecified } \\
\text { hyperkinetic } \\
\text { manifestations) }\end{array}$ & $\begin{array}{l}\text { ICD-9 code } \\
314.01 \text { (ADD with } \\
\text { hyperactivity). }\end{array}$ & $\begin{array}{l}\text { ICD-9 codes } 314 \\
\text { (includes ADD } \\
\text { with and without } \\
\text { hyperactivity, } \\
\text { hyperkinesis with } \\
\text { developmental } \\
\text { delay, } \\
\text { hyperkinetic } \\
\text { conduct disorder, } \\
\text { other or } \\
\text { unspecified } \\
\text { hyperkinetic } \\
\text { manifestations). }\end{array}$ & $\begin{array}{l}\text { ICD-9-CM code } \\
314.0 \text { (ADD } \\
\text { without and with } \\
\text { hyperactivity). }\end{array}$ & $\begin{array}{l}\text { ICD-9 codes } 314 \\
\text { (includes ADD } \\
\text { with and without } \\
\text { hyperactivity, } \\
\text { hyperkinesis with } \\
\text { developmental } \\
\text { delay, } \\
\text { hyperkinetic } \\
\text { conduct disorder, } \\
\text { other or } \\
\text { unspecified } \\
\text { hyperkinetic } \\
\text { manifestations) } \\
\text { and ICD-10 } \\
\text { codes F90 } \\
\text { (includes } \\
\text { disturbance of } \\
\text { activity and } \\
\text { attention, } \\
\text { hyperkinetic } \\
\text { conduct disorder, } \\
\text { other or } \\
\text { unspecified } \\
\text { hyperkinetic } \\
\text { disorder) or } \\
\text { ADHD medication } \\
\text { prescription. }\end{array}$ & $\begin{array}{l}\text { ICD-9 codes } 314 \\
\text { (includes ADD } \\
\text { with and without } \\
\text { hyperactivity, } \\
\text { hyperkinesis with } \\
\text { developmental } \\
\text { delay, } \\
\text { hyperkinetic } \\
\text { conduct disorder, } \\
\text { other or } \\
\text { unspecified } \\
\text { hyperkinetic } \\
\text { manifestations) } \\
\text { and F90 (includes } \\
\text { disturbance of } \\
\text { activity and } \\
\text { attention, } \\
\text { hyperkinetic } \\
\text { conduct disorder, } \\
\text { other or } \\
\text { unspecified } \\
\text { hyperkinetic } \\
\text { disorder). }\end{array}$ \\
\hline
\end{tabular}


TABLE 1 | Continued

\begin{tabular}{|c|c|c|c|c|c|c|c|c|}
\hline & $\begin{array}{l}\text { Walitza et al. } \\
\text { (2007) }\end{array}$ & $\begin{array}{l}\text { Golimstok et al. } \\
\text { (2011) }\end{array}$ & $\begin{array}{l}\text { Curtin et al. } \\
\text { (2018) }\end{array}$ & $\begin{array}{l}\text { Fluegge and } \\
\text { Fluegge (2018) }\end{array}$ & $\begin{array}{l}\text { Tzeng et al. } \\
(2019)\end{array}$ & Fan et al. (2020) & $\begin{array}{l}\text { Du Rietz et al. } \\
\text { (2021) }\end{array}$ & $\begin{array}{l}\text { Zhang et al. } \\
\text { (2021) }\end{array}$ \\
\hline $\begin{array}{l}\text { Definition of } \\
\text { later-life } \\
\text { outcome }\end{array}$ & $\begin{array}{l}\text { Clinical diagnosis } \\
\text { of PD. }\end{array}$ & $\begin{array}{l}\text { Probable AD } \\
\text { based on } \\
\text { NINCDS/ ADRDA } \\
\text { criteria (McKhann } \\
\text { et al., 1984). } \\
\text { DLB based on } \\
\text { consensus } \\
\text { criteria (McKeith } \\
\text { et al., 1996). }\end{array}$ & $\begin{array}{l}\text { ICD-9-CM codes } \\
332.0 \text { (PD), } 332.1 \\
\text { (secondary } \\
\text { parkinsonism), } \\
333.0 \text { (other } \\
\text { degenerative } \\
\text { basal ganglia } \\
\text { diseases), } 333.1 \\
\text { (essential and } \\
\text { other specified } \\
\text { forms of tremor). }\end{array}$ & $\begin{array}{l}\text { ICD-9 codes } \\
331.0 \text { (AD) and } \\
331.82 \text { (LBD). }\end{array}$ & $\begin{array}{l}\text { ICD-9-CM codes } \\
290.0 \text { (senile } \\
\text { dementia), } \\
\text { 290.10-290.13 } \\
\text { (presenile } \\
\text { dementia, } \\
\text { uncomplicated or } \\
\text { with delirium or } \\
\text { delusional or } \\
\text { depressive } \\
\text { features), } \\
\text { 290.20-290.21, } \\
\text { 290.3 (senile } \\
\text { dementia with } \\
\text { delusional or } \\
\text { depressive } \\
\text { features or } \\
\text { delirium), 290.4, } \\
\text { 290.41-290.43 } \\
\text { (vascular } \\
\text { dementia, } \\
\text { uncomplicated or } \\
\text { with delirium or } \\
\text { delusional or } \\
\text { depressed } \\
\text { mood), } \\
290.8-290.9 \\
\text { (other or } \\
\text { unspecified senile } \\
\text { psychotic } \\
\text { condition), and } \\
\text { 331.0 } \\
\text { (Alzheimer's } \\
\text { disease). }\end{array}$ & $\begin{array}{l}\text { ICD-9-CM code } \\
332.0(P D) \text { with at } \\
\text { least } 3 \text { outpatient } \\
\text { visits or hospital } \\
\text { admissions and } \\
\text { at least one PD } \\
\text { medication. }\end{array}$ & $\begin{array}{l}\text { ICD-8 codes } \\
342.00 \text { (PD), } \\
342.08-342.09 \\
\text { (other defined or } \\
\text { unspecified } \\
\text { parkinsonism); } \\
\text { ICD-9 codes } \\
\text { 332.0 (PD), 332.1 } \\
\text { (secondary } \\
\text { parkinsonism), } \\
\text { 333.0 (other } \\
\text { degenerative } \\
\text { diseases of the } \\
\text { basal ganglia); } \\
\text { ICD-10 codes } \\
\text { G20 (PD), G21.2 } \\
\text { (secondary } \\
\text { parkinsonism due } \\
\text { to other external } \\
\text { agents), G21.3 } \\
\text { (postencephalitic } \\
\text { parkinsonism), } \\
\text { G21.8-G21.9 } \\
\text { (other defined or } \\
\text { unspecified } \\
\text { secondary } \\
\text { parkinsonism), } \\
\text { G23.1 } \\
\text { (progressive } \\
\text { supranuclear } \\
\text { ophthalmoplegia), } \\
\text { G23.2 } \\
\text { (striatonigral } \\
\text { degeneration), } \\
\text { G23.8 (other } \\
\text { specified } \\
\text { degenerative } \\
\text { diseases of basal } \\
\text { ganglia), G23.9 } \\
\text { (unspecified } \\
\text { degenerative } \\
\text { disease of basal } \\
\text { ganglia), G25.9 } \\
\text { (unspecified } \\
\text { extrapyramidal } \\
\text { and movement } \\
\text { disorder). }\end{array}$ & $\begin{array}{l}\text { AD: ICD-7 codes } \\
304 \text { (senile } \\
\text { psychosis), } 305 \\
\text { (presenile } \\
\text { psychosis); ICD-8 } \\
\text { code 290 } \\
\text { (dementia senile } \\
\text { and presenile); } \\
\text { ICD-9 codes } \\
\text { 290A (senile } \\
\text { dementia), 290B } \\
\text { (presenile } \\
\text { dementia, } \\
\text { onset < 65 years), } \\
\text { 290X (dementia } \\
\text { associated with } \\
\text { aging, } \\
\text { unspecified), } \\
\text { 331A (presenile } \\
\text { and senile } \\
\text { degeneration of } \\
\text { the Alzheimer's } \\
\text { type); ICD-10 } \\
\text { codes F00 } \\
\text { (dementia in AD), } \\
\text { F03 (unspecified } \\
\text { dementia), G30 } \\
\text { (AD). } \\
\text { Other dementias: } \\
\text { ICD-7 code } 306 \\
\text { (psychosis with } \\
\text { arteriosclerosis of } \\
\text { the brain); ICD-8 } \\
\text { codes 293.0 } \\
\text { (psychosis of } \\
\text { central nervous } \\
\text { system with } \\
\text { cerebral } \\
\text { arterioles), 293.1 } \\
\text { (psychosis of } \\
\text { central nervous } \\
\text { system without } \\
\text { cerebrovascular } \\
\text { disease); ICD-9 } \\
\text { codes 290E } \\
\text { (multi-infarction } \\
\text { dementia), 290W }\end{array}$ \\
\hline
\end{tabular}


TABLE 1 | Continued

Walitza et al.

Golimstok et al.

Curtin et al.

Fluegge and

Tzeng et al.

(2019)

Fan et al. (2020)

Du Rietz et al.

(2021)

Zhang et al.

(2021)

(other specified

age-related

dementia), 294B

(dementia in

somatic disease

classified

elsewhere), 331B

(Pick's

syndrome), $331 \mathrm{C}$

(senile

degeneration of

the brain of

unspecified type),

$331 \times$ (cerebral
degeneration,

unspecified);

ICD-10 codes

F01 (vascular

dementia), F02

(dementia in other

diseases

Covariates No participant

was taking

stimulant

medication. No

other covariates

considered.

Patients matched

to controls by

age, sex and

education. No

participant was

taking stimulant

medication. No

other covariates

considered.

$\begin{array}{llll}\begin{array}{l}\text { Adjusted for sex, } \\ \text { age, }\end{array} & \text { Adjusted for } & \text { Adjusted for age, } & \text { Adjusted for } \\ \text { race/ethnicity, } & \text { diabetes (clinical } & \text { sex, } & \text { Charlson } \\ \text { psychotic } & \text { classification } & \text { comorbidities, } & \text { Comorbidity } \\ \text { conditions, } & \text { software } & \text { geographical } & \text { Index. } \\ \text { tobacco use. } & \text { diagnostic } & \text { area, } & \\ & \text { category 50) and } & \begin{array}{l}\text { urbanization, } \\ \text { income. }\end{array} \\ & \text { obesity (not } & \text { incrise } & \\ & \text { otherwise } & \\ & \text { specified, code } & & \\ \text { 278.00). } & & \end{array}$

elsewhere), F05.

(delirium with

underlying

dementia), G31.1

(senile

degeneration of

brain, not

elsewhere

classified), G31.8

(other specified

degenerative

diseases of

nervous system).

Adjusted for birth year of index

persons and of

relatives, and sex

of index persons

and of relatives.

Adjusted for sex and birth year of account for

different follow-up

lengths). 
TABLE 1 | Continued

\begin{tabular}{|c|c|c|c|c|c|c|c|c|}
\hline & $\begin{array}{l}\text { Walitza et al. } \\
(2007)\end{array}$ & $\begin{array}{l}\text { Golimstok et al. } \\
\text { (2011) }\end{array}$ & $\begin{array}{l}\text { Curtin et al. } \\
\text { (2018) }\end{array}$ & $\begin{array}{l}\text { Fluegge and } \\
\text { Fluegge (2018) }\end{array}$ & $\begin{array}{l}\text { Tzeng et al. } \\
\text { (2019) }\end{array}$ & Fan et al. (2020) & $\begin{array}{l}\text { Du Rietz et al. } \\
\text { (2021) }\end{array}$ & $\begin{array}{l}\text { Zhang et al. } \\
\text { (2021) }\end{array}$ \\
\hline Results & $\begin{array}{l}\text { On the WURS-k, } \\
\text { group differences } \\
\text { on the 'Attention } \\
\text { deficit/hyperactivity' } \\
\text { subscale } \\
(0.8 \pm 0.8 \text { in } \\
\text { patients and } \\
0.6 \pm 0.6 \text { in } \\
\text { controls, } \\
p=0.01) \text {. } \\
\text { No differences in } \\
\text { frequencies } \\
\text { clinical childhood } \\
\text { diagnosis of } \\
\text { ADHD between } \\
\text { patients (10.2\%) } \\
\text { and controls } \\
\text { (6.8\%, } p= \\
0.418) .\end{array}$ & $\begin{array}{l}\text { ADHD was } \\
\text { significantly more } \\
\text { frequent in DLB } \\
(47.8 \%) \text { than in } \\
A D(15.2 \%) \text { or } \\
\text { controls }(15.1 \%) . \\
\text { ORLBDvsControl }=5.1 \\
{[95 \% \mathrm{Cl}=2.7-9.6] .}\end{array}$ & $\begin{array}{l}\text { Incident BG\&C } \\
\text { was significantly } \\
\text { more frequent in } \\
\text { ADHD (0.52\%) } \\
\text { than in controls } \\
(0.19 \%) . \\
\text { aHRBG } \\
{[95 \% \mathrm{Cl}=2.4} \\
\text { Incident PD was } \\
\text { significantly more } \\
\text { frequent in } \mathrm{ADHD} \\
(0.18 \%) \text { than in } \\
\text { controls (0.06\%). } \\
\text { aHRPD }=2.6 \\
{[95 \% \mathrm{Cl}=1.8-3.7] \text {. }} \\
\text { When including } \\
\text { only } \mathrm{ADHD} \text { not } \\
\text { taking stimulant } \\
\text { medication: } \\
\text { aHRBG\&C }=1.8 \\
{[95 \% \mathrm{Cl}=1.4-2.3]} \\
\text { and aHRPD }=2.3 \\
\text { [95\% } \mathrm{Cl}=1.5-3.5] \text {. }\end{array}$ & $\begin{array}{l}\mathbb{I R R} \angle \mathrm{LBD}=1.16 \\
{[95 \% \mathrm{Cl}=1.01-1.32]} \\
\text { adjusted for } \\
\text { diabetes. } \\
\mathrm{RRR}_{\mathrm{LBD}}=1.06 \\
{[95 \% \mathrm{Cl}=0.95-1.18,} \\
\text { n.s. }) \text { adjusted for } \\
\text { diabetes and } \\
\text { obesity. }\end{array}$ & 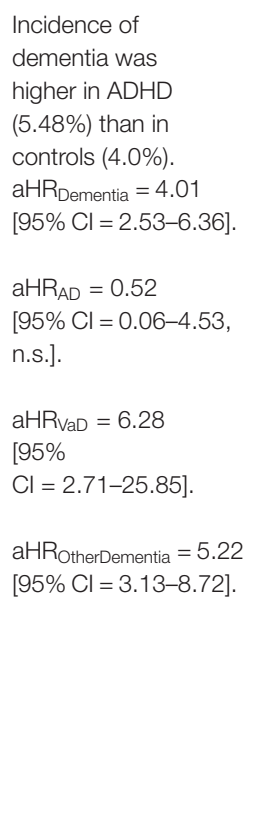 & $\begin{array}{l}\text { Prior diagnosis of } \\
\text { ADHD was more } \\
\text { frequent in PD } \\
(0.13 \%) \text { than in } \\
\text { controls }(0.05 \%) . \\
\text { Adjusted } \\
\mathrm{OR}=3.65 \\
{[95 \% \mathrm{Cl}=2.26-10.50] \text {. }}\end{array}$ & $\begin{array}{l}\text { Individuals with } \\
\text { ADHD had } \\
\text { increased risk of } \\
\text { all physical } \\
\text { conditions except } \\
\text { rheumatoid } \\
\text { arthritis. } \\
\text { ORPD }=1.50 \\
{[95 \% \mathrm{Cl}=1.08-2.09] \text {. }} \\
\text { OR } \\
{[95 \% \mathrm{Cl}=1.86-3.19] \text {. }}\end{array}$ & $\begin{array}{l}\text { Higher risk of } A D \\
\text { and dementia in } \\
\text { family members } \\
\text { of index persons } \\
\text { with } A D H D \\
\text { compared to } \\
\text { family members } \\
\text { of index persons } \\
\text { without ADHD. } \\
\text { Parents: } \\
\text { aHR } \\
\text { [95\% } \mathrm{Cl}=1.55 \\
\text { aHR } 1.26-1.89] \text { ) } \\
\text { [95\% } \mathrm{Cl}=1.11-1.63] \text {. } \\
\text { Grandparents: } \\
\text { aHR } \\
\text { [95\% } \mathrm{Cl}=1.11 \\
\text { aHR }=1.08-1.13] \text {. } \\
{[95 \%} \\
\mathrm{Cl}=1.08-1.12] .\end{array}$ \\
\hline
\end{tabular}

Notes. -: not reported/not applicable. AD, Alzheimer's Disease/Dementia; ADD, Attention Deficit Disorder; ADHD, Attention-Deficit Hyperactivity Disorder; aHR, adjusted Hazards ratio; BG\&C, Basal Ganglia and Cerebellar Disorders; CI Confidence Interval; CM, Clinical Modification; DSM-IV, Diagnostic and Statistical Manual of Mental Disorders Fourth Edition; ICD, International Classification of Diseases; IRR, incidence rate ratio; LBD, Lewy Body Diseases; OR, Odds Ratio; PD, Parkinson's Disease; WURS-k, Wender Utah Rating Scale-German short version. 
(Table 1). For example, two studies considered "secondary parkinsonism" (Curtin et al., 2018; Du Rietz et al., 2021) among the outcomes of interest, however secondary parkinsonism is not necessarily neurodegenerative (Shin and Chung, 2012) and may have potentially confounded results. The multiple aetiologies present within the outcome samples result in a very heterogenous group of diagnoses that may not be particularly attributed to LBD, and precludes robust conclusions about the specific association between ADHD and neurodegenerative LBD.

There is also considerable worldwide variability in the use of the ICD versions, with some countries implementing "clinical modifications" that modify ICD codes according to country-specific needs, e.g., ICD-9-CM and ICD-10-CM in the US, or ICD-10-CA in Canada (Otero Varela et al., 2021). These modifications can either include more detailed coding to characterize a patient's state (generating more individual codes than the original version) or be used to simplify the index terms of the ICD. Overall, this leads to variability in the number of codes and categories, as well as definitions in each modified ICD (Jetté et al., 2010), which compromises comparability of data between countries.

The extent to which ICD codes actually correspond to the presence of a disease or disorder has been examined in multiple studies of ADHD (e.g., O'Malley et al., 2005; Daley et al., 2017) and neurogenerative diseases (Wermuth et al., 2012; Muzerengi et al., 2017; Wilkinson et al., 2018; Harding et al., 2019), and misdiagnosis rates as high as $80 \%$ have been reported (O'Malley et al., 2005). A systematic review found that healthcare data had low sensitivity $(<50 \%)$ for identifying all types of dementia (Wilkinson et al., 2018). The diagnosis of AD or LBD relies heavily on complex clinical criteria (McKhann et al., 2011; McKeith et al., 2017) which makes them more difficult to code than conditions where specific diagnostic tests can confirm the diagnosis [e.g., diabetes (St. Germaine-Smith et al., 2012)]. An examination of ICD codes in the Danish National Hospital Register (Wermuth et al., 2012) found that $18 \%$ of patients coded as having idiopathic Parkinson's disease did not meet consensus criteria upon careful review of clinical features. Especially in Parkinson's disease, misdiagnoses are common (Feldman et al., 2012; Harding et al., 2019), calling into question the use of different clinical standards across different health registries and individual health centers. A previous study examining the accuracy of ICD-9-CM codes in identifying cases of parkinsonism found that using medications listed in pharmacy data was more accurate than using medical records (Swarztrauber et al., 2005), which was also corroborated by a Swedish study (Hjerpe et al., 2010).

Error rates in ICD coding for ADHD may also be high, in part because clinicians seldom actually establish that all ADHD diagnostic criteria are present, even when an ICD code of ADHD is recorded consistently across visits (Daley et al., 2017). At most, only about half of clinicians explicitly quantify ADHD symptoms, and fewer than $15 \%$ formally document whether symptoms fall above the clinical threshold (Daley et al., 2017). Further errors can be introduced because ICD codes are generally not assigned by clinicians themselves, but by coders based on clinicians' notes (O'Malley et al., 2005), and therefore depend on the clarity and consistency of the terminology used in the notes. As such, ICD codes do not always reflect a clear and systematic ascertainment of symptom severity, functional impairment, childhood onset, or ruling out other possible aetiologies. This is rather problematic in the context of examining relationships between $\mathrm{ADHD}$ and neurodegeneration, because ADHD-like experiences (inattention, distractibility, impulsivity, and emotional dysregulation) can be neuropsychiatric indicators of neurodegenerative disease onset (Ismail et al., 2018; Bateman et al., 2020), and establishing whether they are due to ADHD or to neurodegeneration is key.

The selection of controls in these studies does not include systematic assessment to rule out $\mathrm{ADHD}$. This is problematic because, especially in adults, ADHD is underdiagnosed (Newcorn et al., 2007; Ginsberg et al., 2014). In one article (Tzeng et al., 2019), ADHD prevalence was $0.07 \%$, whereas worldwide adult prevalence is consistently closer to $3 \%$ (Polanczyk et al., 2007; Kooij et al., 2016), suggesting that up to $2.9 \%$ of the "non-ADHD" group may in fact have had ADHD, for overall rates to be on par with expected prevalence. A recent study (Chen et al., 2019) using the same Taiwanese National Health Insurance registry identified 275,980 ADHD participants over 12 years (23,000 new cases annually), significantly more than the 675 ADHD cases identified within the 1-year enrolment period in Tzeng et al. (2019), suggesting many missed cases in Tzeng and colleagues' investigation.

Lastly, it should be noted that two studies in this review used data from either inpatient hospitalization visits (Fluegge and Fluegge, 2018) or a minimum of three outpatient visits (Tzeng et al., 2019), which likely biased the samples towards severe ADHD or patients with chronic illnesses or health comorbidities resulting in increased doctor's visits. Indeed, three annual outpatient visits is uncommon for adults with ADHD; the mean is closer to one annual visit (Garcia-Argibay et al., 2021). Additional comorbidities leading to multiple hospital visits may account for dementia risk in these studies (Vassilaki et al., 2015), particularly in older adults for whom comorbidities are increased (Chen et al., 2018). Moreover, evaluating ADHD as a predictor of hospitalization for $\mathrm{LBD}$ or $\mathrm{AD}$ is not equivalent to evaluating it as a predictor of the development of these conditions, especially as $\mathrm{ADHD}$ on its own is recognized to be associated with an increased risk of hospitalization (Chien et al., 2017; Lindemann et al., 2017). As such, the methodological approaches used in these studies preclude the authors' inference that there exists an "association between antecedent ADHD and dementia risk" (Fluegge and Fluegge, 2018).

\section{Definitions of ADHD}

In two case-control studies of interest (Walitza et al., 2007; Golimstok et al., 2011), the researchers did not actually diagnose ADHD but rather ascertained symptom frequencies and used cut-off scores to classify participants into "ADHD" and "nonADHD" groups. Symptom rating scales provide data that must be taken as only one component of a broad clinical assessment (Ramsay, 2017) including a comprehensive clinical history and corroborating reports (Sibley et al., 2012; Sibley, 2021). Further, traits of inattention, hyperactivity and impulsivity 
are endorsed by $60 \%$ of adults (Das et al., 2012), and their use cannot provide any conclusions about whether clinical $\mathrm{ADHD}$ is associated with neurodegenerative disease outcomes. It is also possible that some adults may overreport normal cognitive or behavioral fluctuations as symptoms of ADHD, or experience distractibility or disorganization in the absence of clinically significant impairment, both of which preclude a clinical diagnosis of ADHD (Sibley, 2021).

In quantifying childhood symptoms, neither study considered potential confounding factors that may have accounted for symptomatology. It is crucial to ascertain that inattention/hyperactivity in childhood is truly attributable to $\mathrm{ADHD}$ and not to other factors such as traumatic brain injury (Lee et al., 2013) or Asperger syndrome (Tani et al., 2006), for example. Ruling out alternative explanations for symptoms is a key step in ensuring diagnostic accuracy when assessing ADHD in adults (Sibley, 2021), and failure to do so often results in an overestimation of symptoms attributable to ADHD (Sibley et al., 2017). Inquiring about these antecedents is also critical to determine whether they can account for any significant variance in neurodegenerative disease risk. Brain injury, hypertension, physical inactivity, cardiovascular risk factors, and excessive alcohol and tobacco consumption have all been linked to dementia risk (Bergland et al., 2017; Livingston et al., 2020) and many have been shown to be increased in ADHD as well (Callahan et al., 2017). As such, they should be considered potential confounds and should be controlled for in study designs or statistical models.

\section{Representativeness of Patient Samples}

In a smaller case control study (Golimstok et al., 2011), participants were identified as positive cases of ADHD if they demonstrated both current and childhood symptoms. As a result, cases of remitted ADHD_generally thought to represent at least $50-60 \%$ of ADHD cases (Sibley et al., 2017) - were unaccounted for. It is unclear if or how the dementia and control groups differed in their prevalence of remitted ADHD, but this has important implications for understanding relationships between ADHD in early life and later neurodegenerative disease risk. Notably, prevalence of ADHD in this study was roughly five times higher in the control group (15.1\%) relative to expected frequencies of ADHD in the general adult or older adult population ( $\sim 3 \%$; Michielsen et al., 2012; Kooij et al., 2016), strongly implying faulty recall and/or an unrepresentative sample.

In examining neurodegenerative disease outcomes, some studies included early-onset disease cases (Walitza et al., 2007; Curtin et al., 2018). This may introduce bias, because specific genetic mutations account for early-onset LBD (EscottPrice et al., 2015; Ylönen et al., 2017) and these patients are genotypically and phenotypically different from patients with later onset (Schrag and Schott, 2006; Ferguson et al., 2016; Post et al., 2020). In one study (Walitza et al., 2007), the early-onset group comprised $48.9 \%$ of all patients with Parkinson's disease, yet the population prevalence of early-onset cases is approximately 5-10\% of all Parkinson's disease cases (Wickremaratchi et al., 2009; Mehanna et al., 2014), suggesting the sample may not be representative of, or generalizable to, Parkinson's disease as a whole. Notably, the sex distribution in Curtin and colleagues' (Curtin et al., 2018) Parkinson's disease sample (44\% female) is not typical of this disorder, in which males outnumber females 1.5-2:1 (Haaxma et al., 2007), also calling into question the representativeness of their sample.

No studies accounted for attrition, despite acknowledgements that at least some participants withdrew from initial eligible samples (Tzeng et al., 2019) and despite the fact that attrition rates are typically quite high in longitudinal studies of $\mathrm{ADHD}$ (e.g., Hartsough et al., 1996). Only one of the studies (Golimstok et al., 2011) considered education in their analyses, despite the fact that adults with ADHD typically have lower educational attainment (Biederman et al., 2008) which may account for important variance in dementia risk (Sharp and Gatz, 2011). Furthermore, previous research has shown that males have a twoto four-times higher risk of developing a neurodevelopmental disorder such as ADHD than females (May et al., 2019), and males have a higher risk of Parkinson's disease than females (Haaxma et al., 2007), while there is a slightly higher risk for females of developing dementia with Lewy bodies (Mouton et al., 2018). Despite these sex differences, only three of the studies considered sex as a covariate in their statistical models (Curtin et al., 2018; Tzeng et al., 2019; Du Rietz et al., 2021) and one matched groups on sex (Golimstok et al., 2011). Lastly, all articles except two (Tzeng et al., 2019; Fan et al., 2020) disregarded obvious risk factors for developing dementia, such as traumatic brain injury, hypertension, physical inactivity, cardiovascular risk factors, excessive alcohol consumption, and smoking (Bergland et al., 2017; Livingston et al., 2020). Many of these risk factors are increased in ADHD, including traumatic brain injury (Liou et al., 2018), hypertension (Fuemmeler et al., 2011), cardiovascular risk factors (Cortese et al., 2013; Irmisch et al., 2013; Chen et al., 2018; Du Rietz et al., 2021), and smoking (Galéra et al., 2017), and these factors may be accounting for a substantial portion of the putative association between ADHD and later-life neurodegenerative disease (as in Bendayan et al., 2020, for example).

\section{Recall Biases}

In two studies (Walitza et al., 2007; Golimstok et al., 2011), participants with mild dementia and healthy controls were asked to self-rate ADHD symptoms during early childhood, to determine whether antecedent $\mathrm{ADHD}$ was more frequent in the mild dementia group. In one study (Golimstok et al., 2011), corroborating evidence may have been supplemented by an informant who knew the participant for at least 10 years but not necessarily since childhood. In our view (Sharma et al., 2021), retrospective self-report in older adults-requiring recall from $>40$ years prior-severely compromises the validity of the data being collected, particularly in samples composed of individuals with cognitive impairment. Even young adults are poor historians of their childhood ADHD symptoms: nearly $40 \%$ of 22-year-old adults who do not recall their childhood symptoms actually did have $\mathrm{ADHD}$ as children, and roughly $60 \%$ remember symptoms that, in fact, were not present 
TABLE 2 | Evaluation of the quality of the eight studies in this review using the Newcastle-Ottawa Scale.

Case-control studies

\begin{tabular}{|c|c|c|c|c|c|c|c|c|c|}
\hline & $\begin{array}{l}\text { Is the case definition (ND } \\
\text { outcome) adequate? }\end{array}$ & $\begin{array}{l}\text { Representativeness of } \\
\text { the cases }\end{array}$ & Selection of controls & $\begin{array}{l}\text { Definition of } \\
\text { controls }\end{array}$ & $\begin{array}{l}\text { Comparability } \\
\text { of groups }\end{array}$ & $\begin{array}{l}\text { Ascertainment } \\
\text { of exposure }\end{array}$ & $\begin{array}{l}\text { Same method } \\
\text { of } \\
\text { ascertainment } \\
\text { for cases and } \\
\text { controls? }\end{array}$ & $\begin{array}{l}\text { Non-response } \\
\text { rate }\end{array}$ & Overall quality \\
\hline Walitza et al. (2007) & $\begin{array}{l}\text { Known medical diagnosis } \\
\text { is }\end{array}$ & $\begin{array}{l}\text { No; sample was enriched } \\
\text { for early-onset PD }\end{array}$ & Community controls is & $\begin{array}{l}\text { No history of } \\
\text { PD मे }\end{array}$ & $\begin{array}{l}\text { Groups not } \\
\text { matched, and } \\
\text { no adjustment } \\
\text { for confounds }\end{array}$ & $\begin{array}{l}\text { Symptom } \\
\text { count in } \\
\text { childhood } \\
\text { based on } \\
\text { retrospective } \\
\text { self-report }\end{array}$ & Yes $\vec{k}$ & $\begin{array}{l}\text { Same in both } \\
\text { groups }(0 \%) \text { मे }\end{array}$ & $5 / 9$ \\
\hline Fan et al. (2020) & $\begin{array}{l}\text { ICD 9-CM code of PD with } \\
\geq 3 \text { outpatient visits or } \\
\text { hospital admissions and } \\
\text { receiving PD medication }\end{array}$ & Yes मु & $\begin{array}{l}\text { Same sample as cases, } \\
\text { but unclear if controls } \\
\text { constitute a } \\
\text { hospitalized sample }\end{array}$ & $\begin{array}{l}\text { Figure } \\
1 \text { indicates } \\
\text { controls were } \\
\text { 'subjects } \\
\text { without PD' है }\end{array}$ & 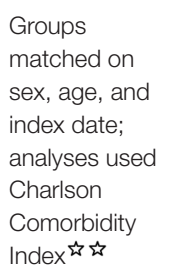 & $\begin{array}{l}\text { ICD-9-CM } \\
\text { code of } 314.0 \\
\text { (ADD with and } \\
\text { without } \\
\text { hyperactivity) }\end{array}$ & Yes $\vec{n}$ & $\begin{array}{l}\text { Same in both } \\
\text { groups }(0 \%) \text { is }\end{array}$ & $6 / 9$ \\
\hline \multirow[t]{3}{*}{$\begin{array}{l}\text { Golimstok et al. } \\
\text { (2011) }\end{array}$} & $\begin{array}{l}\text { Probable AD based on } \\
\text { NINCDS/ADRDA criteria } \\
\text { (Lindemann et al., 2017). } \\
\text { DLB based on consensus } \\
\text { criteria (Chien et al., 2017); } \\
\text { diagnoses based on several } \\
\text { sources मै }\end{array}$ & Yes मे & $\begin{array}{l}\text { Same sample as cases, } \\
\text { but unclear if controls } \\
\text { constitute a } \\
\text { hospitalized sample }\end{array}$ & $\begin{array}{l}\text { No history of } \\
\text { ND } \not\end{array}$ & $\begin{array}{l}\text { Groups } \\
\text { matched on } \\
\text { sex, age, } \\
\text { geographic } \\
\text { area, and } \\
\text { education is is }\end{array}$ & $\begin{array}{l}\text { DSM-IV criteria } \\
\text { ascertained by } \\
\text { clinician blind to } \\
\text { case/control } \\
\text { status म } \\
\text { Retrospective } \\
\text { self-report }\end{array}$ & Yes मे & $\begin{array}{l}\text { Same in both } \\
\text { groups }(0 \%) \text { मे }\end{array}$ & $8 / 9$ \\
\hline & \multicolumn{9}{|c|}{ Cohort studies } \\
\hline & $\begin{array}{l}\text { Representativeness of } \\
\text { the exposed cohort }\end{array}$ & $\begin{array}{l}\text { Selection of the } \\
\text { non-exposed cohort }\end{array}$ & $\begin{array}{l}\text { Ascertainment of } \\
\text { exposure }^{a}\end{array}$ & $\begin{array}{l}\text { Demonstration } \\
\text { that outcome } \\
\text { of interest } \\
\text { was not } \\
\text { present at } \\
\text { start of study }\end{array}$ & $\begin{array}{l}\text { Comparability } \\
\text { of cohorts on } \\
\text { the basis of } \\
\text { the design or } \\
\text { analysis }\end{array}$ & $\begin{array}{l}\text { Assessment } \\
\text { of outcome }\end{array}$ & $\begin{array}{l}\text { Was follow-up } \\
\text { long enough } \\
\text { for outcomes } \\
\text { to occur }\end{array}$ & $\begin{array}{l}\text { Adequacy of } \\
\text { follow up of } \\
\text { cohorts }\end{array}$ & \\
\hline Curtin et al. (2018) & $\begin{array}{l}\text { Included several non-ADHD } \\
\text { hyperkinetic syndromes }\end{array}$ & $\begin{array}{l}\text { Drawn from the same } \\
\text { population as the exposed } \\
\text { cohort it }\end{array}$ & $\begin{array}{l}\text { ICD 9-CM codes linked } \\
\text { to Utah Population } \\
\text { Database }\end{array}$ & $\begin{array}{l}\text { Patients were } \\
\text { excluded if } \\
\text { BG\&C } \\
\text { disorders were } \\
\text { present prior to } \\
\text { an index ADHD } \\
\text { diagnosis or } \\
\text { before age } 21 \\
\text { it }\end{array}$ & $\begin{array}{l}\text { Matched on } \\
\text { sex and birth } \\
\text { year; analyses } \\
\text { controlled for } \\
\text { race, ethnicity, } \\
\text { psychotic } \\
\text { conditions and } \\
\text { tobacco use } \\
\text { ڤు }\end{array}$ & $\begin{array}{l}\text { ICD 9-CM } \\
\text { codes linked to } \\
\text { Utah } \\
\text { Population } \\
\text { Database } \text { 的 }\end{array}$ & $\begin{array}{l}1996-2016 \\
\text { (median } \\
\text { follow-up was } \\
21 \text { years) }\end{array}$ & $\begin{array}{l}2.5 \% \text { cases lost } \\
\text { to follow-up } \\
\text { vs. }<1 \% \\
\text { controls; } \\
\text { statistical } \\
\text { models } \\
\text { included a } \\
\text { competing risk } \\
\text { of death } \vec{\hbar}\end{array}$ & $8 / 9$ \\
\hline
\end{tabular}


TABLE 2 | Continued

\begin{tabular}{|c|c|c|c|c|c|c|c|c|c|}
\hline & \multicolumn{9}{|c|}{ Cohort studies } \\
\hline & $\begin{array}{l}\text { Representativeness of } \\
\text { the exposed cohort }\end{array}$ & $\begin{array}{l}\text { Selection of the } \\
\text { non-exposed cohort }\end{array}$ & $\begin{array}{l}\text { Ascertainment of } \\
\text { exposure }^{\mathrm{a}}\end{array}$ & $\begin{array}{l}\text { Demonstration } \\
\text { that outcome } \\
\text { of interest } \\
\text { was not } \\
\text { present at } \\
\text { start of study }\end{array}$ & $\begin{array}{l}\text { Comparability } \\
\text { of cohorts on } \\
\text { the basis of } \\
\text { the design or } \\
\text { analysis }\end{array}$ & $\begin{array}{l}\text { Assessment } \\
\text { of outcome }\end{array}$ & $\begin{array}{l}\text { Was follow-up } \\
\text { long enough } \\
\text { for outcomes } \\
\text { to occur }\end{array}$ & $\begin{array}{l}\text { Adequacy of } \\
\text { follow up of } \\
\text { cohorts }\end{array}$ & \\
\hline $\begin{array}{l}\text { Fluegge and } \\
\text { Fluegge (2018) }\end{array}$ & $\begin{array}{l}\text { Only considered ADD with } \\
\text { hyperactivity (not inattentive } \\
\text { presentation); only } \\
\text { considered hospitalization } \\
\text { for ADHD }\end{array}$ & $\begin{array}{l}\text { Drawn from the same } \\
\text { population as the exposed } \\
\text { cohort }\end{array}$ & $\begin{array}{l}\text { ICD 9-CM codes linked } \\
\text { to the Healthcare Cost } \\
\text { and Utilization Project }\end{array}$ & No & $\begin{array}{l}\text { Not stated } \\
\text { whether } \\
\text { cohorts were } \\
\text { comparable; } \\
\text { analyses } \\
\text { adjusted for } \\
\text { age, diabetes } \\
\text { and obesity } \\
\text { 대대 }\end{array}$ & $\begin{array}{l}\text { ICD 9-CM } \\
\text { codes linked to } \\
\text { the Healthcare } \\
\text { Cost and } \\
\text { Utilization } \\
\text { Project }\end{array}$ & $\begin{array}{l}\text { Ten-year lagged } \\
\text { measure }\end{array}$ & $\begin{array}{l}\text { Data were } \\
\text { drawn from the } \\
\text { HCUP, which } \\
\text { includes all } \\
\text { discharge } \\
\text { records since } \\
1988 \text { is }\end{array}$ & $7 / 9$ \\
\hline Tzeng et al. (2019) & $\begin{array}{l}\text { Included several non-ADHD } \\
\text { hyperkinetic syndromes; } \\
\text { exposed cohort restricted } \\
\text { to inpatients, or those with } \\
\geq 3 \text { outpatient visits within } \\
1 \text { year }\end{array}$ & $\begin{array}{l}\text { Drawn from the same } \\
\text { population as the exposed } \\
\text { cohort }\end{array}$ & $\begin{array}{l}\text { ICD 9-CM codes linked } \\
\text { to the National Health } \\
\text { Insurance Program it }\end{array}$ & $\begin{array}{l}\text { Participants } \\
\text { excluded if } \\
\text { dementia was } \\
\text { present before } \\
\text { tracking began } \\
\text { or before an } \\
\text { ADHD } \\
\text { diagnosis कs }\end{array}$ & $\begin{array}{l}\text { Matched on } \\
\text { sex, age, } \\
\text { geographic } \\
\text { area and } \\
\text { urbanization of } \\
\text { residence, } \\
\text { comorbidities, } \\
\text { and income } \\
\text { 引5 }\end{array}$ & $\begin{array}{l}\text { ICD 9-CM } \\
\text { codes linked to } \\
\text { the National } \\
\text { Health } \\
\text { Insurance } \\
\text { Program is }\end{array}$ & 2000-2010 מ & $\begin{array}{l}\text { No information } \\
\text { provided }\end{array}$ & $7 / 9$ \\
\hline $\begin{array}{l}\text { Du Rietz et al. } \\
\text { (2021) }\end{array}$ & $\begin{array}{l}\text { Included several non-ADHD } \\
\text { hyperkinetic syndromes or } \\
\text { individuals prescribed } \\
\text { ADHD medication }\end{array}$ & $\begin{array}{l}\text { Siblings, half-siblings, and } \\
\text { family members, drawn } \\
\text { from the same population } \\
\text { as the exposed cohort }\end{array}$ & $\begin{array}{l}\text { ICD-9 and ICD-10 } \\
\text { codes linked to the } \\
\text { National Patient } \\
\text { Register }\end{array}$ & $\begin{array}{l}\text { No, exposures } \\
\text { and outcomes } \\
\text { were treated as } \\
\text { lifetime } \\
\text { presence or } \\
\text { absence (no } \\
\text { consideration } \\
\text { of onset timing) }\end{array}$ & $\begin{array}{l}\text { Stratified by } \\
\text { sex, and birth } \\
\text { year of relatives } \\
\text { to adjust for } \\
\text { follow-up } \\
\text { lengths斿 }\end{array}$ & $\begin{array}{l}\text { ICD-9 and } \\
\text { ICD-10 codes } \\
\text { linked to the } \\
\text { National Patient } \\
\text { Register }{ }^{\text {r }}\end{array}$ & $\begin{array}{l}\text { All participants } \\
\text { followed from } \\
\text { birth until 2013, } \\
\text { range } \\
18-81 \text { years } \\
\text { (mean = } 47 \text { years) } 25\end{array}$ & $\begin{array}{l}\text { Data were } \\
\text { drawn from the } \\
\text { Total Population } \\
\text { Register } \\
\text { (i.e., includes all } \\
\text { persons living in } \\
\text { Sweden) }\end{array}$ & $7 / 9$ \\
\hline Zhang et al. (2021) & $\begin{array}{l}\text { Included several non-ADHD } \\
\text { hyperkinetic syndromes or } \\
\text { individuals prescribed } \\
\text { ADHD medication }\end{array}$ & $\begin{array}{l}\text { Drawn from the same } \\
\text { population as the exposed } \\
\text { cohort }\end{array}$ & $\begin{array}{l}\text { ICD-9 and ICD-10 } \\
\text { codes linked to the } \\
\text { National Patient } \\
\text { Register }\end{array}$ & $\begin{array}{l}\text { Not applicable, } \\
\text { as the aim was } \\
\text { to evaluate } \\
\text { dementia in } \\
\text { biological } \\
\text { relatives, not } \\
\text { individuals with } \\
\text { ADHD } \\
\text { themselves. }\end{array}$ & 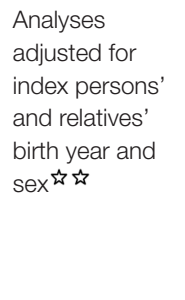 & $\begin{array}{l}\text { ICD-7, ICD-8, } \\
\text { ICD-9, and } \\
\text { ICD-10 codes } \\
\text { linked to the } \\
\text { National Patient } \\
\text { Register }\end{array}$ & $\begin{array}{l}\text { All relatives } \\
\text { followed until } \\
\text { dementia } \\
\text { onset, death, } \\
\text { migration, or } \\
\text { end of study } \\
\text { (median } \\
\text { 8-25 years) is }\end{array}$ & $\begin{array}{l}\text { Data were } \\
\text { drawn from the } \\
\text { Total Population } \\
\text { Register } \\
\text { (i.e., includes all } \\
\text { persons living in } \\
\text { Sweden) }\end{array}$ & $7 / 8$ \\
\hline
\end{tabular}

Notes. ${ }^{\text {T}}$ The Newcastle-Ottawa Scale considers record linkage using ICD codes to be sufficient to confirm certain outcomes of interest, despite the limitations of this methodology to identify neurodegenerative diseases described previously (Wikinson et al., 2018; Harding et al., 2019) and summarized in the manuscript text. AD, Alzheimer's Disease/Dementia; ADD, Attention Deficit Disorder; ADHD, Attention-Deficit Hyperactivity Disorder; BG\&C, Basal Ganglia and Cerebellar Disorders; CM, Clinical Modification; DSM-IV, Diagnostic and Statistical Manual of Mental Disorders Fourth Edition; HCUP, Healthcare Cost and Utilization Project; ICD, International Classification of Diseases; LBD, Lewy Body Diseases; PD, Parkinson's Disease. "Indicates a high-quality choice, with a maximum of one star in all categories except "Comparability" which has a two-star maximum. 
(Breda et al., 2020). A possible recall bias is supported by one study's data (Walitza et al., 2007): healthy control participants (mean age 57.2 years) reported significantly fewer ADHD symptoms relative to the younger healthy normative sample (mean age 29.8 years: Retz-Junginger et al., 2002), whereas it has been established that population samples of younger and older adults should endorse similar rates of ADHD symptoms (Callahan and Plamondon, 2019). Self-report is also less sensitive than informant-report for detecting current and past ADHD symptoms (Zucker et al., 2002; Sibley et al., 2012). Additionally, it is unknown whether participants in these studies were blinded to the study's aims; being "cued" about possible links between antecedent $\mathrm{ADHD}$ and their current condition (LBD) may have inflated their retrospective recall of childhood symptoms.

\section{Balance of Strengths and Weaknesses}

We conducted a formal evaluation of the quality of the eight studies in this review using the Newcastle-Ottawa Scale (Wells et al., 2011), and found many strengths across each (Table 2). All case-control studies had clear criteria for the selection of controls, and two ensured that participants were age- and sex-matched (Golimstok et al., 2011; Fan et al., 2020). Consensus criteria were used in two of the three case-control studies to ascertain neurodegenerative disease outcomes (Walitza et al., 2007; Golimstok et al., 2011). Among cohort studies, strengths included participants drawn from large population cohorts and usually matched on age and sex (or analyses were adjusted for these factors). Follow-up length was at least 10 years in four studies (Curtin et al., 2018; Fluegge and Fluegge, 2018; Tzeng et al., 2019; Du Rietz et al., 2021).

Despite these strengths, two major components required to draw strong conclusions from these studies-ascertainment of exposure (ADHD) and representativeness of the exposed cohort-were flawed across almost all studies: including non-ADHD hyperkinetic syndromes or restricting the sample to those with numerous outpatient visits or hospitalizations results in samples that do not likely represent most ADHD cases, and non-exposed cases were also not systematically assessed to rule out $\mathrm{ADHD}$. Likely, these methodological issues result in a conservative estimate of true effects; that is, without the "noise" generated by the inclusion of non-ADHD cases in the exposed group and potentially missed ADHD in the non-exposed group, associations between exposure and outcome may be even stronger. A second possibility is that the inclusion of non-ADHD cases in the exposed group is driving observed effects. As previously noted, many non-ADHD hyperkinetic disorders-which were included in the exposed cohort in four of the five cohort studies (Curtin et al., 2018; Tzeng et al., 2019;

\section{REFERENCES}

Aarsland, D. (2016). Cognitive impairment in Parkinson's disease and dementia with Lewy bodies. Parkinsonism Relat. Disord. 22, S144-S148. doi: 10.1016/j. parkreldis.2015.09.034

American Psychiatric Association (2013). Diagnostic and Statistical Manual of Mental Disorders, 5th Edn. Arlington, VA: American Psychiatric Publishing.
Du Rietz et al., 2021; Zhang et al., 2021) —are caused by damage to the basal ganglia (Wichmann and DeLong, 2010) and may conceivably predispose one to further later-life basal ganglia dysfunction (a hallmark of LBD, e.g., McKeith et al., 2017). To tease apart these issues will require careful and systematic assessment of ADHD across all participants within future studies, and an examination of neurodegenerative disease risk in ADHD and non-ADHD hyperkinetic syndromes separately.

\section{CONCLUSIONS}

These studies present first evidence of a link between ADHD and risk of dementia, specific to LBD. Strengths include well-powered analyses and extensive follow-up periods ( $>10$ years) in most studies. However, six (Curtin et al., 2018; Fluegge and Fluegge, 2018; Tzeng et al., 2019; Fan et al., 2020; Du Rietz et al., 2021; Zhang et al., 2021) rely on ICD diagnostic codes extracted from electronic health records, and there are limitations around the validity and accuracy of these codes, particularly for a disorder that is notoriously difficult to detect in adults (Newcorn et al., 2007; Ginsberg et al., 2014). The remaining two (Walitza et al., 2007; Golimstok et al., 2011) are limited by potentially biased and inaccurate self-reported retrospective childhood ADHD symptoms in small samples of cognitively impaired participants.

These studies provide tentative support for ADHD as a potential risk factor for later development of a neurodegenerative disease. Due to the methodological limitations and biases we have identified, we argue that the true association between ADHD and neurodegeneration is not yet identifiable. The sources of biases identified here should be considered in future studies to ascertain the true relative risk of neurodegeneration in patients with ADHD. Accurate and systematic diagnoses of ADHD and neurodegeneration are needed.

\section{AUTHOR CONTRIBUTIONS}

BC conceptualized the work. SB, MS, and BC made substantial contributions to the critical analysis and interpretation of data. SB, MS, and BC wrote initial drafts of the manuscript. SB and BC wrote the final draft. All authors revised it critically for important intellectual content, approved the version to be published, and agree to be accountable for all aspects of the work.

\section{FUNDING}

This work was supported by an Eyes High Postdoctoral MatchFunding Fellowship to SB and by a Canada Research Chair to BC.

Asherson, P., Buitelaar, J., Faraone, S. V., and Rohde, L. A. (2016). Adult attentiondeficit hyperactivity disorder: key conceptual issues. Lancet Psychiatry 3, 568-578. doi: 10.1016/S2215-0366(16)30032-3

Barkley, R. (1997). Behavioral inhibition, sustained attention and executive functions: constructing a unifying theory of ADHD. Psychol. Bull. 121, 65-94. doi: 10.1037/0033-2909.121.1.65

Bateman, D. R., Gill, S., Hu, S., Foster, E. D., Ruthirakuhan, M. T., Sellek, A. F., et al. (2020). Agitation and impulsivity in mid and late life as possible 
risk markers for incident dementia. Alzheimer's Dement. (N Y) 6:e12016. doi: $10.1002 / \operatorname{trc} 2.12016$

Baumeister, A. A. (2021). Is attention-deficit/hyperactivity disorder a risk syndrome for Parkinson's disease. Harv. Rev. Psychiatry 29, 142-158. doi: 10.1097/HRP.0000000000000283

Benchimol, E. I., Manuel, D. G., To, T., Griffiths, A. M., Rabeneck, L., and Guttmann, A. (2011). Development and use of reporting guidelines for assessing the quality of validation studies of health administrative data. J. Clin. Epidemiol. 64, 821-829. doi: 10.1016/j.jclinepi.2010.10.006

Bendayan, R., Mascio, A., Stewart, R., Roberts, A., and Dobson, R. J. (2020). Cognitive trajectories in comorbid dementia with schizophrenia or bipolar disorder: the south london and maudsley nhs foundation trust biomedical research centre (SLaM BRC) case register. Am. J. Geriatr. Psychiatry 29, 604-616. doi: 10.1016/j.jagp.2020.10.018

Bergland, A. K., Dalen, I., Larsen, A. I., Aarsland, D., and Soennesyn, H. (2017). Effect of vascular risk factors on the progression of mild Alzheimer's disease and lewy body dementia. J. Alzheimer's Dis. 56, 575-584. doi: 10.3233/JAD160847

Biederman, J., and Faraone, S. V. (2005). Attention-deficit hyperactivity disorder. Lancet 366, 237-248. doi: 10.1016/S0140-6736(05)66915-2

Biederman, J., Petty, C. R., Fried, R., Kaiser, R., Dolan, C. R., Schoenfeld, S., et al. (2008). Educational and occupational underattainment in adults with attention-deficit/hyperactivity disorder: a controlled study. J. Clin. Psychiatry 69, 1217-1222. doi: 10.4088/jcp.v69n0803

Breda, V., Rohde, L. A., Menezes, A. M. B., Anselmi, L., Caye, A., Rovaris, D. L., et al. (2020). Revisiting ADHD age-of-onset in adults: to what extent should we rely on the recall of childhood symptoms. Psychol. Med. 50, 857-866. doi: 10.1017/S003329171900076X

Callahan, B. L., Bierstone, D., Stuss, D. T., and Black, S. E. (2017). Adult ADHD: risk factor for dementia or phenotypic mimic. Front. Aging Neurosci. 9, 1-15. doi: $10.3389 /$ fnagi.2017.00260

Callahan, B. L., and Plamondon, A. (2019). Examining the validity of the ADHD concept in adults and older adults. CNS Spectr. 24, 518-525. doi: $10.1017 /$ S1092852918001190

Callahan, B. L., Ramakrishnan, N., Shammi, P., Bierstone, D., Taylor, R., Ozzoude, M., et al. (2021). Cognitive and neuroimaging profiles of older adults with attention deficit/hyperactivity disorder presenting to a memory clinic. J. Atten. Disord. doi: 10.1177/10870547211060546. [Online ahead of print].

Chen, V.C.-H., Chan, H.-L., Wu, S.-I., Lee, M., Lu, M.-L., Liang, H.-Y., et al. (2019). Attention-deficit/hyperactivity disorder and mortality risk in Taiwan. JAMA Netw. Open. 2:e198714. doi: 10.1001/jamanetworkopen. 2019.8714

Chen, Q., Hartman, C. A., Haavik, J., Harro, J., Klungsøyr, K., Hegvik, T.-A., et al. (2018). Common psychiatric and metabolic comorbidity of adult attentiondeficit/hyperactivity disorder: a population-based cross-sectional study. PLoS One 13:e0204516. doi: 10.1371/journal.pone.0204516

Chen, M.-H., Pan, T.-L., Hsu, J.-W., Huang, K.-L., Su, T.-P., Li, C.-T., et al. (2018). Risk of type 2 diabetes in adolescents and young adults with attention-deficit/hyperactivity disorder. J. Clin. Psychiatry 79:17m11607. doi: $10.4088 / \mathrm{JCP} .17 \mathrm{~m} 11607$

Chien, W.-C., Chung, C.-H., Lin, F.-H., Yeh, C.-B., Huang, S.-Y., Lu, R.-B., et al. (2017). The risk of injury in adults with attention-deficit hyperactivity disorder: a nationwide, matched-cohort, population-based study in Taiwan. Res. Dev. Disabil. 65, 57-73. doi: 10.1016/j.ridd.2017.04.011

Cortese, S., Faraone, S. V., Bernardi, S., Wang, S., and Blanco, C. (2013). Adult attention-deficit hyperactivity disorder and obesity: epidemiological study. $\mathrm{Br}$. J. Psychiatry 203, 24-34. doi: 10.1192/bjp.bp.112.123299

Culpepper, L., and Mattingly, G. (2010). Challenges in identifying and managing attention-deficit/hyperactivity disorder in adults in the primary care setting: a review of the literature. Prim. Care Companion J. Clin. Psychiatry 12, e1-e17. doi: 10.4088/PCC.10r00951pur

Curtin, K., Fleckenstein, A. E., Keeshin, B. R., Yurgelun-Todd, D. A., Renshaw, P. F., Smith, K. R., et al. (2018). Increased risk of diseases of the basal ganglia and cerebellum in patients with a history of attentiondeficit/hyperactivity disorder. Neuropsychopharmacology 43, 2548-2555. doi: 10.1038/s41386-018-0207-5

Daley, M. F., Newton, D. A., DeBar, L., Newcomer, S. R., Pieper, L., Boscarino, J. A., et al. (2017). Accuracy of electronic health record-derived data for the identification of incident ADHD. J. Atten. Disord. 21, 416-425. doi: $10.1177 / 1087054713520616$

Das, D., Cherbuin, N., Butterworth, P., Anstey, K., and Easteal, S. (2012). A population-based study of attention deficit/hyperactivity disorder symptoms and associated impairment in middle-aged adults. PLoS One 7, 1-9. doi: 10.1371/journal.pone.0031500

Du Rietz, E., Brikell, I., Butwicka, A., Leone, M., Chang, Z., Cortese, S., et al. (2021). Mapping phenotypic and aetiological associations between ADHD and physical conditions in adulthood in Sweden: a genetically informed register study. Lancet. Psychiatry 8, 774-783. doi: 10.1016/S2215-0366(21) 00171-1

Escott-Price, V. for International Parkinson's Disease Genomics Consortium, Nalls, M. A., Morris, H. R., Lubbe, S., Brice, A., Gasser, T.et al. (2015). Polygenic risk of Parkinson disease is correlated with disease age at onset. Ann. Neurol. 77, 582-591. doi: 10.1002/ana.24335

Fan, H.-C., Chang, Y.-K., Tsai, J.-D., Chiang, K.-L., Shih, J.-H., Yeh, K.-Y., et al. (2020). The association between Parkinson's disease and attentiondeficit hyperactivity disorder. Cell Transplant. 29:963689720947416. doi: 10.1177/0963689720947416

Faraone, S. V., Asherson, P., Banaschewski, T., Biederman, J., Buitelaar, J. K., Ramos-Quiroga, J. A., et al. (2015). Attention-deficit/hyperactivity disorder. Nat. Rev. Dis. Primers 1:15020. doi: 10.1038/nrdp.2015.20

Fayyad, J., Sampson, N. A., Hwang, I., Adamowski, T., Aguilar-Gaxiola, S., Al-Hamzawi, A., et al. (2017). The descriptive epidemiology of DSM-IV Adult ADHD in the World Health Organization World Mental Health Surveys. Atten. Defic. Hyperact. Disord. 9, 47-65. doi: 10.1007/s12402-016 $-0208-3$

Feldman, A. L., Johansson, A. L. V., Gatz, M., Flensburg, M., Petzinger, G. M., Widner, H., et al. (2012). Accuracy and sensitivity of parkinsonian disorder diagnoses in two Swedish national health registers. Neuroepidemiology 38, 186-193. doi: $10.1159 / 000336356$

Ferguson, L. W., Rajput, A. H., and Rajput, A. (2016). Early-onset vs. late-onset Parkinson's disease: a clinical-pathological study. Can. J. Neurol. Sci. 43, 113-119. doi: $10.1017 /$ cjn.2015.244

Fluegge, K., and Fluegge, K. (2018). Antecedent ADHD, dementia and metabolic dysregulation: A U.S. based cohort analysis. Neurochem. Int. 112, 255-258. doi: 10.1016/j.neuint.2017.08.005

Fuemmeler, B. F., Østbye, T., Yang, C., McClernon, F. J., and Kollins, S. H. (2011). Association between attention-deficit/hyperactivity disorder symptoms and obesity and hypertension in early adulthood: a population-based study. Int. J. Obes. 35, 852-862. doi: 10.1038/ijo.2010.214

Galéra, C., Salla, J., Montagni, I., Hanne-Poujade, S., Salamon, R., Grondin, O., et al. (2017). Stress, attention deficit hyperactivity disorder (ADHD) symptoms and tobacco smoking: the i-share study. Eur. Psychiatry 45, 221-226. doi: 10.1016/j.eurpsy.2017.07.007

Garcia-Argibay, M., Pandya, E., Ahnemark, E., Werner-Kiechle, T., Andersson, L. M., Larsson, H., et al. (2021). Healthcare utilization and costs of psychiatric and somatic comorbidities associated with newly diagnosed adult ADHD. Acta Psychiatr. Scand. 144, 50-59. doi: 10.1111/acps. 13297

Gibbins, C., Weiss, M. D., Goodman, D. W., Hodgkins, P. S., Landgraf, J. M., and Faraone, S. V. (2010). ADHD-hyperactive/impulsive subtype in adults. Ment. Illn. 2, e9-e9. doi: 10.4081/mi.2010.e9

Ginsberg, Y., Quintero, J., Anand, E., Casillas, M., and Upadhyaya, H. P. (2014). Underdiagnosis of attention-deficit/hyperactivity disorder in adult patients: a review of the literature. Prim Care Companion CNS Disord. 16:PCC.13r01600. doi: 10.4088/PCC.13r01600

Golimstok, A., Rojas, J. I., Romano, M., Zurru, M. C., Doctorovich, D., and Cristiano, E. (2011). Previous adult attention-deficit and hyperactivity disorder symptoms and risk of dementia with Lewy bodies: a case-control study. Eur. J. Neurol. 18, 78-84. doi: 10.1111/j.1468-1331.2010.03064.x

Gomperts, S. N. (2016). Lewy Body Dementias. Continuum 22, 435-463. doi: 10.1212/CON.0000000000000309

Goodman, D. W., Mitchell, S., Rhodewalt, L., and Surman, C. B. H. (2016). Clinical presentation, diagnosis and treatment of attention-deficit hyperactivity disorder (ADHD) in older adults: a review of the evidence and its implications for clinical care. Drugs Aging 33, 27-36. doi: 10.1007/s40266-0150327-0 
Goulardins, J. B., Marques, J. C. B., and De Oliveira, J. A. (2017). Attention deficit hyperactivity disorder and motor impairment. Percept. Mot. Skills 124, 425-440. doi: 10.1177/0031512517690607

Haaxma, C. A., Bloem, B. R., Borm, G. F., Oyen, W. J. G., Leenders, K. L., Eshuis, S., et al. (2007). Gender differences in Parkinson's disease. J. Neurol. Neurosurg. Psychiatry 78, 819-824. doi: 10.1136/jnnp.2006.103788

Harding, Z., Wilkinson, T., Stevenson, A., Horrocks, S., Ly, A., Schnier, C., et al. (2019). Identifying Parkinson's disease and parkinsonism cases using routinely collected healthcare data: a systematic review. PLoS One 14:e0198736. doi: 10.1371/journal.pone.0198736

Hartsough, C. S., Babinski, L. M., and Lambert, N. M. (1996). Tracking procedures and attrition containment in a long-term follow-up of a community-based ADHD sample. J. Child Psychol. Psychiatry 37, 705-713. doi: 10.1111/j.14697610.1996.tb01462.x

Hjerpe, P., Merlo, J., Ohlsson, H., Bengtsson Boström, K., and Lindblad, U. (2010). Validity of registration of ICD codes and prescriptions in a research database in Swedish primary care: a cross-sectional study in Skaraborg primary care database. BMC Med. Inform. Decis. Mak. 10:23. doi: 10.1186/1472-69 47-10-23

Irmisch, G., Richter, J., Thome, J., Sheldrick, A. J., and Wandschneider, R. (2013). Altered serum mono- and polyunsaturated fatty acid levels in adults with ADHD. ADHD Atten. Deficit Hyperact. Disord. 5, 303-311. doi: 10.1007/s12402-013-0107-9

Ismail, Z., Gatchel, J., Bateman, D. R., Barcelos-Ferreira, R., Chantillon, M., Jaeger, J., et al. (2018). Affective and emotional dysregulation as pre-dementia risk markers: exploring the mild behavioral impairment symptoms of depression, anxiety, irritability and euphoria. Int. Psychogeriatrics 30, 185-196. doi: $10.1017 /$ S1041610217001880

Ivanchak, N., Fletcher, K., and Jicha, G. (2012). Attention-deficit/hyperactivity disorder in older adults: prevalence and possible connections to mild cognitive impairment. Curr. Psychiatry Rep. 14, 552-560. doi: 10.1007/s11920-0120305-8

Jetté, N., Quan, H., Hemmelgarn, B., Drosler, S., Maass, C., Moskal, L., et al. (2010). The development, evolution and modifications of ICD-10: challenges to the international comparability of morbidity data. Med. Care 48, 1105-1110. doi: 10.1097/MLR.0b013e3181ef9d3e

Kieling, R., and Rohde, L. A. (2012). ADHD in children and adults: diagnosis and prognosis. Curr. Top. Behav. Neurosci. 9, 1-16. doi: 10.1007/7854_2010_115

Kompliti, K., and Goetz, C. G. (1998). Hyperkinetic movement disorders misdiagnosed as tics in gilles de la tourette syndrome. Mov. Disord. 13, 477-480. doi: $10.1002 / \mathrm{mds} .870130317$

Konofal, E., Lecendreux, M., and Cortese, S. (2010). Sleep and ADHD. Sleep Med. 11, 652-658. doi: 10.1016/j.sleep.2010.02.012

Kooij, J. J. S., Michielsen, M., Kruithof, H., and Bijlenga, D. (2016). ADHD in old age: a review of the literature and proposal for assessment and treatment. Expert Rev. Neurother. 16, 1371-1381. doi: 10.1080/14737175.2016.1204914

Lee, Y.-K., Hou, S.-W., Lee, C.-C., Hsu, C.-Y., Huang, Y.-S., and Su, Y.-C. (2013). Increased risk of dementia in patients with mild traumatic brain injury: a nationwide cohort study. PLoS One 8:e62422. doi: 10.1371/journal.pone. 0062422

Lindemann, C., Langner, I., Banaschewski, T., Garbe, E., and Mikolajczyk, R. T. (2017). The risk of hospitalizations with injury diagnoses in a matched cohort of children and adolescents with and without attention deficit/hyperactivity disorder in Germany: a database study. Front. Pediatr. 5:220. doi: 10.3389/fped. 2017.00220

Liou, Y.-J., Wei, H.-T., Chen, M.-H., Hsu, J.-W., Huang, K.-L., Bai, Y.-M., et al. (2018). Risk of traumatic brain injury among children, adolescents and young adults with attention-deficit hyperactivity disorder in taiwan. J. Adolesc. Heal. 63, 233-238. doi: 10.1016/j.jadohealth.2018.02.012

Livingston, G., Huntley, J., Sommerlad, A., Ames, D., Ballard, C., Banerjee, S., et al. (2020). Dementia prevention, intervention and care: 2020 report of the lancet commission. Lancet 396, 413-446. doi: 10.1016/S0140-6736(20)30367-6

May, T., Adesina, I., McGillivray, J., and Rinehart, N. J. (2019). Sex differences in neurodevelopmental disorders. Curr. Opin. Neurol. 32, 622-626. doi: 10.1097/WCO.0000000000000714

Mazzali, C., Paganoni, A. M., Ieva, F., Masella, C., Maistrello, M., Agostoni, O., et al. (2016). Methodological issues on the use of administrative data in healthcare research: the case of heart failure hospitalizations in Lombardy region, 2000 to 2012. BMC Health. Serv. Res. 16:234. doi: 10.1186/s12913-0161489-0

McKeith, I. G., Boeve, B. F., Dickson, D. W., Halliday, G., Taylor, J.-P., Weintraub, D., et al. (2017). Diagnosis and management of dementia with Lewy bodies: fourth consensus report of the DLB Consortium. Neurology 89, 88-100. doi: 10.1212/WNL.0000000000004058

McKeith, I. G., Galasko, D., Kosaka, K., Perry, E. K., Dickson, D. W., Hansen, L. A., et al. (1996). Consensus guidelines for the clinical and pathologic diagnosis of dementia with Lewy bodies (DLB): report of the consortium on DLB international workshop. Neurology 47, 1113-1124. doi: 10.1212/wnl.47. 5.1113

McKhann, G., Drachman, D., Folstein, M., Katzman, R., Price, D., and Stadlan, E. M. (1984). Clinical diagnosis of Alzheimer's disease: report of the NINCDS-ADRDA work group ${ }^{*}$ under the auspices of department of health and human services task force on Alzheimer's disease. Neurology 34, 939-939. doi: 10.1212/wnl.34.7.939

McKhann, G. M., Knopman, D. S., Chertkow, H., Hyman, B. T., Jack, C. R., Kawas, C. H., et al. (2011). The diagnosis of dementia due to Alzheimer's disease: recommendations from the national institute on aging-Alzheimer's association workgroups on diagnostic guidelines for Alzheimer's disease. Alzheimers Dement. 7, 263-269. doi: 10.1016/j.jalz.2011.03.005

Mehanna, R., Moore, S., Hou, J. G., Sarwar, A. I., and Lai, E. C. (2014). Comparing clinical features of young onset, middle onset and late onset Parkinson's disease. Parkinsonism. Relat. Disord. 20, 530-534. doi: 10.1016/j.parkreldis.2014.02.013

Michielsen, M., Semeijn, E., Comijs, H. C., Van De Ven, P., Beekman, A. T. F., Deeg, D. J. H., et al. (2012). Prevalence of attention-deficit hyperactivity disorder in older adults in the netherlands. Br. J. Psychiatry 201, 298-305. doi: 10.1192/bjp.bp.111.101196

Mouton, A., Blanc, F., Gros, A., Manera, V., Fabre, R., Sauleau, E., et al. (2018). Sex ratio in dementia with Lewy bodies balanced between Alzheimer's disease and Parkinson's disease dementia: a cross-sectional study. Alzheimers Res. Ther. 10:92. doi: 10.1186/s13195-018-0417-4

Muzerengi, S., Rick, C., Begaj, I., Ives, N., Evison, F., Woolley, R. L., et al. (2017). Coding accuracy for Parkinson's disease hospital admissions: implications for healthcare planning in the UK. Public Health 146, 4-9. doi: 10.1016/j.puhe. 2016.12.024

Newcorn, J. H., Weiss, M., and Stein, M. A. (2007). The complexity of ADHD: diagnosis and treatment of the adult patient with comorbidities. CNS Spectr. 12, 1-6. doi: 10.1017/s1092852900026158

O’Malley, K. J., Cook, K. F., Price, M. D., Wildes, K. R., Hurdle, J. F., and Ashton, C. M. (2005). Measuring diagnoses: ICD code accuracy. Health Serv. Res. 40, 1620-1639. doi: 10.1111/j.1475-6773.2005.00444.x

Otero Varela, L., Doktorchik, C., Wiebe, N., Quan, H., and Eastwood, C. (2021). Exploring the differences in ICD and hospital morbidity data collection features across countries: an international survey. BMC Health. Serv. Res. 21:308. doi: 10.1186/s12913-021-06302-w

Polanczyk, G., de Lima, M. S., Horta, B. L., Biederman, J., and Rohde, L. A. (2007). The worldwide prevalence of ADHD: a systematic review and metaregression analysis. Am. J. Psychiatry 164, 942-948. doi: 10.1176/ajp.2007.164.6.942

Pollack, J. (2012). Distinguishing between adult ADHD and mild cognitive impairment. Curr. Psychiatry 8, 48-48.

Post, B., van den Heuvel, L., van Prooije, T., van Ruissen, X., van de Warrenburg, B., and Nonnekes, J. (2020). Young onset Parkinson's disease: a modern and tailored approach. J. Parkinsons Dis. 10, S29-S36. doi: 10.3233/JPD-202135

Ramsay, J. R. (2017). Assessment and monitoring of treatment response in adult ADHD patients: current perspectives. Neuropsychiatr. Dis. Treat. 13, 221-232. doi: 10.2147/NDT.S104706

Retz-Junginger, P., Retz, W., Blocher, D., Weijers, H.-G., Trott, G.-E., Wender, P. H., et al. (2002). Wender utah rating scale (WURS-k) die deutsche kurzform zur retrospektiven erfassung des hyperkinetischen syndroms bei erwachsenen. Nervenarzt 73, 830-838. doi: 10.1007/s00115-001-1215-x

Rosler, M., Casas, M., Konofal, E., and Buitelaar, J. (2010). Attention deficit hyperactivity disorder in adults. World J. Biol. Psychiatry 11, 684-698. doi: 10.3109/15622975.2010.483249

Salvi, V., Migliarese, G., Venturi, V., Rossi, F., Torriero, S., Viganò, V., et al. (2019). ADHD in adults: clinical subtypes and associated characteristics. Riv. Psichiatr. 54, 84-89. doi: 10.1708/3142.31249 
Schrag, A., and Schott, J. M. (2006). Epidemiological, clinical and genetic characteristics of early-onset parkinsonism. Lancet Neurol. 5, 355-363. doi: 10.1016/S1474-4422(06)70411-2

Sezgin, M., Bilgic, B., Tinaz, S., and Emre, M. (2019). Parkinson's disease dementia and lewy body disease. Semin. Neurol. 39, 274-282. doi: 10.1055/s-00391678579

Sharma, M. J., Lavoie, S., and Callahan, B. L. (2021). A call for research on the validity of the age-of-onset criterion application in older adults being evaluated for ADHD: a review of the literature in clinical and cognitive psychology. Am. J. Geriatr. Psychiatry 29, 669-678. doi: 10.1016/j.jagp.2020. 10.016

Sharp, E. S., and Gatz, M. (2011). Relationship between education and dementia: an updated systematic review. Alzheimer Dis. Assoc. Disord. 25, 289-304. doi: 10.1097/WAD.0b013e318211c83c

Shin, H.-W., and Chung, S. J. (2012). Drug-induced parkinsonism. J. Clin. Neurol. 8, 15-21. doi: 10.3988/jcn.2012.8.1.15

Sibley, M. H. (2021). Empirically-informed guidelines for first-time adult ADHD diagnosis. J. Clin. Exp. Neuropsychol. 43, 340-351. doi: 10.1080/13803395.2021. 1923665

Sibley, M. H., Pelham, W. E., Molina, B. S. G., Gnagy, E. M., Waxmonsky, J. G., Waschbusch, D. A., et al. (2012). When diagnosing ADHD in young adults emphasize informant reports, DSM items and impairment. J. Consult. Clin. Psychol. 80, 1052-1061. doi: 10.1037/a0029098

Sibley, M. H., Rohde, L. A., Swanson, J. M., Hechtman, L. T., Molina, B. S. G., Mitchell, J. T., et al. (2017). Late-onset ADHD reconsidered with comprehensive repeated assessments between ages 10 and 25. Am. J. Psychiatry 175, 140-149. doi: 10.1176/appi.ajp.2017.17030298

St. Germaine-Smith, C., Metcalfe, A., Pringsheim, T., Roberts, J. I., Beck, C. A., Hemmelgarn, B. R., et al. (2012). Recommendations for optimal ICD codes to study neurologic conditions. Neurology 79, 1049-1055. doi: 10.1212/WNL. ob013e3182684707

Swarztrauber, K., Anau, J., and Peters, D. (2005). Identifying and distinguishing cases of parkinsonism and Parkinson's disease using ICD-9 CM codes and pharmacy data. Mov. Disord. 20, 964-970. doi: 10.1002/mds.20479

Tani, P., Lindberg, N., Appelberg, B., Nieminen-von Wendt, T., von Wendt, L., and Porkka-Heiskanen, T. (2006). Childhood inattention and hyperactivity symptoms self-reported by adults with asperger syndrome. Psychopathology 39, 49-54. doi: 10.1159/000089910

Thorell, L. B., Holst, Y., Chistiansen, H., Kooij, J. J. S., Bijlenga, D., and Sjöwall, D. (2017). Neuropsychological deficits in adults age 60 and above with attention deficit hyperactivity disorder. Eur. Psychiatry 45, 90-96. doi: 10.1016/j.eurpsy. 2017.06.005

Tzeng, N.-S., Chung, C.-H., Lin, F.-H., Yeh, C.-B., Huang, S.-Y., Lu, R.B., et al. (2019). Risk of dementia in adults with ADHD: a nationwide, population-based cohort study in Taiwan. J. Atten. Disord. 23, 995-1006. doi: 10.1177/1087054717714057

Vassilaki, M., Aakre, J. A., Cha, R. H., Kremers, W. K., St. Sauver, J. L., Mielke, M. M., et al. (2015). Multimorbidity and risk of mild cognitive impairment. J. Am. Geriatr. Soc. 63, 1783-1790. doi: 10.1111/jgs.13612

Volkow, N. D., and Swanson, J. M. (2013). Adult attention deficit-hyperactivity disorder. $N$ Engl. J. Med. 369, 1935-1944. doi: 10.1056/NEJMcp12 12625
Walitza, S., Melfsen, S., Herhaus, G., Scheuerpflug, P., Warnke, A., Muller, T., et al. (2007). Association of Parkinson's disease with symptoms of attention deficit hyperactivity disorder in childhood. J. Neural Transm. 72, 311-315. doi: 10.1007/978-3-211-73574-9_38

Wells, G. A., Shea, B., O'Connell, D. T., Peterson, J., Welch, V., Losos, M., et al. (2011). The Newcastle-Ottawa Scale (NOS) for Assessing the Quality of Nonrandomised Studies in MetaAnalyses. Ottawa, ON: The Ottawa Hospital. Available online at: http://www.ohri.ca/programs/clinical_epidemiology/oxford.asp.

Wermuth, L., Lassen, C. F., Himmerslev, L., Olsen, J., and Ritz, B. (2012). Validation of hospital register-based diagnosis of Parkinson's disease. Dan. Med. J. 59:A4391.

Wichmann, T., DeLong, M. R.. (2010). "Basal ganglia, functional organization," in Encyclopedia of Movement Disorders, eds K. Kompoliti and L. V. Metman. Oxford: Academic Press, 118-125. Available online at: https://www. sciencedirect.com/science/article/pii/B9780123741059004378.

Wickremaratchi, M. M., Perera, D., O’Loghlen, C., Sastry, D., Morgan, E., Jones, A., et al. (2009). Prevalence and age of onset of Parkinson's disease in Cardiff: a community based cross sectional study and meta-analysis. J. Neurol. Neurosurg. Psychiatry 80, 805-807. doi: 10.1136/jnnp.2008.162222

Wilkinson, T., Ly, A., Schnier, C., Rannikmäe, K., Bush, K., Brayne, C., et al. (2018). Identifying dementia cases with routinely collected health data: A systematic review. Alzheimer's Dement. 14, 1038-1051. doi: 10.1016/j.jalz.2018.02.016

Ylönen, S., Siitonen, A., Nalls, M. A., Ylikotila, P., Autere, J., Eerola-Rautio, J., et al. (2017). Genetic risk factors in Finnish patients with Parkinson's disease. Parkinsonism. Relat. Disord. 45, 39-43. doi: 10.1016/j.parkreldis.2017.09.021

Zhang, L., Du Rietz, E., Kuja-Halkola, R., Dobrosavljevic, M., Johnell, K., Pedersen, N. L., et al. (2021). Attention-deficit/hyperactivity disorder and Alzheimer's disease and any dementia: a multi-generation cohort study in Sweden. Alzheimer's Dement. doi: 10.1002/alz.12462. [Online ahead of print].

Zucker, M., Morris, M. K., Ingram, S. M., Morris, R. D., and Bakeman, R. (2002). Concordance of self- and informant ratings of adults' current and childhood attention-deficit/hyperactivity disorder symptoms. Psychol. Assess. 14, 379-389. doi: 10.1037//1040-3590.14.4.379

Conflict of Interest: The authors declare that the research was conducted in the absence of any commercial or financial relationships that could be construed as a potential conflict of interest.

Publisher's Note: All claims expressed in this article are solely those of the authors and do not necessarily represent those of their affiliated organizations, or those of the publisher, the editors and the reviewers. Any product that may be evaluated in this article, or claim that may be made by its manufacturer, is not guaranteed or endorsed by the publisher.

Copyright (C) 2022 Becker, Sharma and Callahan. This is an open-access article distributed under the terms of the Creative Commons Attribution License (CC BY). The use, distribution or reproduction in other forums is permitted, provided the original author(s) and the copyright owner(s) are credited and that the original publication in this journal is cited, in accordance with accepted academic practice. No use, distribution or reproduction is permitted which does not comply with these terms. 